\title{
TRANSFORMASI PENGAJARAN BAHASA ARAB DI INDONESIA
}

Oleh: Alam Budi Kusuma

Dosen STAIMS Yogyakarta

\begin{abstract}
From the beginning to the present Arabic teaching in Indonesia got shifting and changing: from lesehan system (sitting on floor) to classical system; from the grammatical-translation method to the direct one; from the separated presentation in presenting the Arabic material to the integrated one; and from the structural approach to the communicative one. Although some approaches, methods, and presentation system had been tried in implication, the success in Arabic teaching was still far from the expectation, moreover if compared with the other languages teaching, like English.
\end{abstract}

\section{Abstrak}

Sejak kali pertama sampai sekarang pengajaran bahasa Arab di Indonesia mengalami pergeseran dan perubahan: dari hanya sistem lesehan menjadi bertambah dengan sistem klasikal; dari menggunakan metode gramatika-terjemah lalu menggunakan metode langsung; dari penyajian materi bahasa Arab dengan sistem terpisah semata kepada penggunaan sistem terpadu juga; dan dari menggunakan pendekatan struktural menjadi pendekatan komunikatif. Meskipun telah mencoba beragam pendekatan, metode, dan sistem penyajian, keberhasilan pengajaran bahasa Arab tampak masih jauh dari yang diharapkan, apalagi bila dibandingkan dengan pengajaran bahasa asing lain seperti bahasa Inggris

\section{A. Pendahuluan}

Bahwa mayoritas masyarakat Indonesia beragama Islam adalah sebuah fakta yang dapat dilihat semua orang, bahasa Arab merupakan bahasa ritual keagamaan adalah sesuatu yang diyakini oleh umat muslim sebuah keyakinan atas penggunaan 


\section{Alam Budi Kusuma : Transformasi Pengajaran Bahasa Arab}

bahasa Arab dalam ritual agama bagi beberapa kalangan muslim, terkadang tidak ditempatkan secara proporsional hingga tidak dibedakan antara al ashly dan al far'iy antara "ajaran" dan "budaya," dan antara kedudukan bahasa Arab dalam shalat dan kedudukan bahasa Arab dalam doa; dan bahwa dalam bahasa Indonesia, bahasa pengantar resmi masyarakat Indonesia ditemukan banyak kata serapan dari bahasa Arab adalah kenyataan lain yang tidak terbantahkan. ${ }^{129}$

Fakta keyakinan dan kenyataan ini secara teoritis menunjukkan paling tidak dua hal: bahasa Arab telah memiliki ruang yang kondusif bagi perkembangannya, dan masyarakat Indonesia telah cukup akrab dengan bahasa Arab.

Sayangnya, sebagaimana dalam banyak hal selalu ditemukan kesenjangan antara teori dan praktek atau antara potensi dan aktualisasi, maka kesenjangan yang sama juga terjadi dalam posisi bahasa Arab di Indonesia. Bahasa Arab, bagi mayoritas masyarakat muslim, ternyata masih terasa sebagai "beban" impor dari luar.

Di sini, beberapa pertanyaan pun patut diajukan: apa yang membuat bahasa Arab terasa sebagai momok meskipun ia menjadi bahasa ritual keagamaan dan telah lama dikenal

129 Bagi Sudarno, bahasa Arab merupakan sumber pengambilan kata-kata bahasa Indonesia paling tua kedua setelah bahasa Sansekerta. Ini didasarkan pada prasasti Talang Tuo, Palembang, yang berbahasa Sansekerta dan bertarikh 684 M, dan syair berbahasa campuran antara bahasa Arab, Sansekerta, dan Indonesia (asli) pada batu nisan bertarikh 1380 Mdi Minye Tujoh, Aceh. Namun, menurut pengakuan Sudarno, tidaklah mudah menentukan berapa dan bagaimana wujud kata-kata bahasa Indonesia serapan dari bahasa Arab. Akbar, tertib, daerah, topan, hakim, dan mahkamah adalah beberapa contoh yang dapat disebut. Lihat, Sudarno, Kata Serapan dari Bahasa Arab, (Jakarta: Arikha Media Cipta, 1992), cet. II, 16-18 dan 62-65. 


\section{Alam Budi Kusuma : Transformasi Pengajaran Bahasa Arab}

mayoritas masyarakat Indonesia? karena watak bahasa Arabkah yang sulit dicerna akibat memiliki sistem yang kompleks atau karena cara penyampaiannya yang tidak realiable dan applicable? Atau, pada dasarnya pengajarannya telah realiable dan applicable, akan tetapi karena ada idola-idola lain, seperti bahasa Inggris dan Mandarin, akibat faktor sosial dan ekonomis, maka bahasa Arab terkesan meminjam istilah dalam fiksi sebagai "antagonis"? Kemungkinan pertama, yaitu watak bahasa arab yang sulit, dapat dikesampingkan bila kebermaknaan istilah-istilah seperti "langue" Saussure, "competence" Noam Chomsky, dan "general linguistic" dipertimbangkan ${ }^{130}$ sedangkan menyebut "kemenangan" bahasa non-Arab sebagai akibat dukungan faktor-faktor eksternal semata juga tidak cukup beralasan. Satu-satunya yang layak dicurigai sebagai penyebab ketidakpopuleran dan momok bahasa Arab adalah cara pengajaran.

130 Langue dalam konsep Saussure menyaran pada sejenis kode, sistem yang dimiliki bersama oleh pemakai suatu bahasa atau semacam kamus yang dibagikan dan ada pada setiap orang; dan Competence dalam konsep Chomsky menunjuk pada "al kifâ$a h$ "/kemampuan potensial yang dimiliki oleh pemakai bahasa untuk memproduksi dan memahami beragam kalimat dengan mudah. Meskipun Langue menyiratkan adanya sistem bahasa yang berbeda sehingga makna competence juga layak ditempatkan dalam kerangka sistem bahasa tertentu, maka adanya istilah general linguistic bermakna bahwa sistem antar bahasa mengandung ciri-ciri yang sama. Dus, setiap orang dalam sebuah sistem bahasa memiliki potensi untuk memahami sistem bahasa yang lain. Lihat, Ferdinad de Saussure, Pengantar Linguistik Umum, terjem. Oleh Rahayu S. Hidayat, (Yogyakarta: Gadjah Mada University Press, 1996), cet. III, hal. 74-81; Mahmûd Sulaimân Yâqût, Manhaj al Bahst al Lughawy, (Iskandariyah: Dâr al Ma'rifah al Jâmi'iyyah, 2002), hal. 144; dan Jos Daniel Parera, Pengantar Linguitik Umum: Kisah Zaman, (Ende-Flores: Nusa Indah, 1977), hal. 15. 


\section{Alam Budi Kusuma : Transformasi Pengajaran Bahasa Arab}

Oleh karena itu, melihat pengajaran bahasa Arab yang selama ini berlaku dan dikembangkan di Indonesia tidak saja terdengar menarik, tetapi bahkan cukup mendesak. Pengetahuan tentang sejarah pengajaran bahasa Arab bisa membantu menjelaskan mengapa bahasa Arab dewasa ini kurang mendapat tempat bahkan di kalangan muslim sendiri bila dibandingkan dengan misalnya bahasa Inggris dan selanjutnya dapat membantu mengkonstruk atau mendisain cara yang tepat dan jitu bagi upaya mendekatkan bahasa Arab pada masyarakat Indonesia. Sejak kapan bahasa Arab mulai diajarkan, bagaimana pengajaran itu dilakukan, apa metode pengajaran yang ditempuh, mengapa pengajaran dilakukan dengan cara tertentu, dan apa kira-kira pendekatan yang digunakan dalam pengajaran bahasa Arab serta bagaimana perkembangannya dari masa ke masa adalah beberapa pertanyaan yang ingin dijawab dalam tulisan ini.

Hanya saja, tulisan ini dihadirkan dengan satu kesadaran akan adanya problem metodologis dalam pembahasannya: rentang waktu yang cukup panjang, ruang lingkup pembahasan yang luas di satu sisi, dan keterbatasan literatur di sisi lain. Untuk itu, tulisan ini tanpa bermaksud melakukan simplifikasi dan generalisasi hanya akan menyorot beberapa institusi pendidikan Islam (pesantren, madrasah, dan perguruan tinggi Islam). ${ }^{131}$

131 Lembaga pendidikan Islam di Indonesia, jika dilihat dari struktur internal pendidikan Islam dan praktek-praktek pendidikan yang dilaksanakan, ada empat kategori: 1) Pendidikan pondok pesantren, yaitu pendidikan Islam tradisional untuk mengajarkan pada siswa Islam sebagai cara hidup dengan titik tolak pengajaran al Qur'an dan Hadis; 2) Pendidikan madrasah, yaitu pendidikan Islam model Barat, dengan sistem klasikal, untuk menanamkan Islam sebagai landasan hidup dalam diri siswa; 3) Pendidikan umum bernafaskan Islam, yaitu pendidikan Islam melalui pengembangan suasana pendidikan bernafaskan Islam pada institusi-institusi 
Bahan tulisan tidak hanya didasarkan pada data tertulis, tetapi juga pengamatan langsung dan tidak langsung dari mendengar cerita orang lain. Dengan demikian, tulisan ini lebih tepat dianggap sebagai pengantar "hidangan" diskusi tentang perkembangan pengajaran bahasa Arab di Indonesia.

\section{B. Antara Praktik Berbahasa dan Belajar Bahasa Arab}

Sebagaimana telah disebut di atas bahwa bahasa Arab adalah bagian yang tidak terpisahkan dari ritual Islam. Shalat lima waktu, misalnya, berisi bacaan-bacaan berbahasa Arab yang diyakini oleh mayoritas Umat Islam sebagai rukun shalat sehingga tidak bisa digantikan dengan bahasa lain. Bahkan, ketika seseorang menyatakan masuk Islam, maka ia harus mengikrarkannya dengan apa yang biasa disebut "kalimah al syahâdah" yang juga berbahasa Arab. Akaq nikah dan pembuka khutbah jum'at adalah contoh lain yang bisa disebut. Akibatnya, tidak ada orang muslim yang tidak pernah berbahasa Arab, karena ia pasti pernah mengucapkan dua kalimah syahadah meskipun ia mungkin tidak melakukan ritual Islam seperti shalat.

Oleh karena itu, meskipun sulit menentukan kapan persisnya bahasa Arab dipakai dan diajarkan di Indonesia, dapatlah dipastikan bahwa awal mula pemakaian dan pengajaran bahasa Arab di Indonesia adalah sejak Islam masuk atau pendidikan Islam di Indonesia dimulai. Tentu saja, kapan, tahun berapa, dan siapa yang mula-mula memasukkan Islam atau

pendidikan umum; dan 4) Pelajaran agama pada lembaga umum sebagai mata kuliah atau pelajaran saja. Lihat, Yasmadi, Modernisasi Pesantren: Kritik Nurcholish Madjid terhadap Pendidikan Islam Tradisional, (Jakarta: Ciputat Press, 2002), hal. 58-59. 


\section{Alam Budi Kusuma : Transformasi Pengajaran Bahasa Arab}

memulai pendidikan Islam di Indonesia juga tidak jelas dan tidak dapat dipastikan. Abad ke-11 atau ke-12 disebut-sebut oleh banyak sumber sebagai awal Islam masuk ke kepulauan nusantara melalui kota-kota pantai. ${ }^{132}$ Penyerapan bahasa Arab oleh masyarakat Indonesia dan perkembangannya kemudian berlangsung seiring dan sejalan dengan perkembangan agama Islam di nusantara. 133

Bahasa Arab pertama-tama "terajarkan" penulis lebih memilih kata terajarkan dari pada diajarkan karena sifat ketidaklangsungan pengajaran bahasa Arab melalui pengajaran doa-doa shalat dan surat-surat pendek al Qur'an, yaitu juz terakhir yang biasa disebut "juz 'amma" atau "turutan." Di dalam turutan ini termuat pula materi pelajaran membaca huruf al Qur'an dengan "metode abjadiyah" (alpabhetic method). Dalam perkembangan selanjutnya pengajaran verbalistik ini dirasa tidak

132 Mastuhu, Dinamika Sistem Pendidikan Pesantren, (Jakarta: INIS, 1994), Seri INIS 20, hal. 20.

133 Istilah pesantren berasal dari kata santri yang diberi imbuhan awalan pe dan akhiran an yang menunjukan arti tempat. Sedangkan menurut Sudjoko Prasodjo, pesantren adalah lembaga pendidikan dan pengajaran agama Islam, umumnya dengan cara nonklasikal, dimana seorang kyai mengajarkan ilmu agama Islam kepada santri-santri berdasarkan kitab yang ditulis dalam bahasa Arab oleh ulama abad pertengahan, dan para sanri biasanya tinggal di pondok (asrama) dalam pesantren tersebut. Menurut Nurcholish Madjid, sistem pesantren merupakan sesuatu yang bersifat asli atau indegienus Indonesia, sehingga dengan sendirinya bernilai positif dan harus dikembangkan. Dalam Nurcholish Madjid, Bilik-Bilik Pesantren Sebuah Potret Perjalanan (Jakarta: Paramadina, 1997), hal. 103. Tidak ada catatan sejarah, kapan waktu munculnya pesantren. Peneliti tarekat dan tradisi Islam asal Belanda, Martin Van Bruinessen, menyatakan tidak mengetahui kapan lembaga tersebut muncul untuk pertama kalinya. Pesantren merupakan satu-satunya lembaga pendidikan yang tahan terhadap berbagai gelombang modernisasi. Lihat. Suwendi: Sejarah dan Pemikiran Pendidikan Islam (jakarta: Raja Grafindo Persada, 2004), hal. 157. 
cukup. Al Qur'an tidak hanya untuk dibaca dalam ritual shalat, tetapi harus dipahami dan ajaran-ajarannya diamalkan. Demikian pula doa-doa dan bacaan shalat perlu dipahami agar shalat benar-benar menjadi media komunikasi dengan Allah, bukan sebagai bentuk "kemabukan" atau ketidaksadaran. Lantas, lahirlah bentuk pengajaran dengan tujuan pendalaman ajaran agama Islam. Ilmu-ilmu bahasa Arab seperti nahwu, sharaf, dan balaghah menjadi bagian dari materi pelajaran bahasa Arab di samping materi-materi fiqh, akidah, dan tafsir. ${ }^{134}$

Pada bentuk kedua inilah, menurut penulis, bahasa Arab mulai "diajarkan" sedangkan sebelumnya bahasa Arab baru "terajarkan." Bila terajarkannya bahasa melahirkan fenomena "praktik berbahasa Arab," maka diajarkannya bahasa Arab melahirkan fenomena "belajar bahasa Arab." Bila praktek berbahasa berkembang melalui dalam istilah Mahmud Yunus "pengajian al Qur'an," maka belajar bahasa dikembangkan dalam "pengajian kitab."135 Jika yang pertama menjadikan al Qur'an sebagai rujukan, maka yang kedua menggunakan buku teks berbahasa Arab karya ulama klasik sebagai acuan, seperti dlammun, al Ajurûmiyah, Alfiyah Ibni Mâlik, dan jawâhir al Balaghah. Pengajaran bahasa Arab ini tumbuh dan berkembang di pondok pesantren.

\section{Sistem Pengajaran Bahasa Arab: Lesehan dan klasikal}

Selain dalam institusi-institusi pendidikan pemerintah, seperti madrasah (tsanawiyah/aliyah), sulit dibayangkan adanya

134 Ahmad Fuad Effendy, Metodologi Pengajaran Bahasa Arab, (Malang: Misykat, 2004), hal. 22.

135 Mahmud Yunus, Sejarah Pendidikan Islam di Indonesia, (Jakarta: Hidakarya Agung, 1996), hal. 50-51. 


\section{Alam Budi Kusuma : Transformasi Pengajaran Bahasa Arab}

kesamaan sistem pendidikan Islam di Indonesia, apalagi pada masa pemerintahan kolonial. Hal ini pertama-tama karena di masa kolonial, terutama Belanda, kebijakan pendidikan lebih bersifat substantif, dalam arti kebijakan pendidikan mencerminkan apa yang hendak dilakukan oleh Belanda untuk Indonesia, bukan apa yang bangsa Indonesia ingin lakukan. Karena itu, alih-alih membuat arahan sistem pengajaran bahasa Arab yang seragam, pemerintah kolonial Belanda tampak sengaja membiarkan umat Islam, yang merupakan mayoritas penduduk koloni ini tetap bodoh. Pendidikan muslim bukan saja tidak diberi subsidi, tetapi juga harus menghadapi sikap bermusuhan dari para pejabat penting. ${ }^{136}$ Keragaman sistem pengajaran bahasa Arab pada institusi non-pemerintah juga akibat dari ketidaksamaan selera para penggagas dan pengalaman guru/kyai yang mengadakan atau mendirikan institusi pendidikan tersebut.

Hal yang sama juga terjadi di masa pra-kolonial atau sebelum abad ke-17. Oleh karena pendidikan keislaman diatur oleh masing-masing kerajaan Islam, maka sistem pengajaran

136 Pada tahun 1890, pada akhir dominasi liberalisme dalam pemerintahan kolonial, rancangan bantuan untuk sekolah swasta diperkenalkan. Namun, sasaran sebenarnya rancangan ini adalah untuk mengintegrasikan sekolah Kristen yang dijalankan oleh berbagai kelompok misionari ke dalam sistem pendidikan pemerintah, bukan untuk membantu sekolah swasta. Sekolah-sekolah Islam (saat itu ada tiga jenis: sekolah Qur'an, yang memberikan pendidikan sangat dasar dalam mengaji al Qur'an; sekolah tradisional pesantren, sebagai pendidikan agama lanjut; dan tarekat, sebagai pelatihan hukum dan doktrin Islam) tidak termasuk dalam rancangan bantuan ini. Setelah ada tekanan massal, pada tahun 1895 sekolah Islam diikutsertakan dalam rancangan bantuan itu. Hanya saja, banyak pemimpin muslim yang tidak menerima rancangan ini, sehingga mereka tidak mengajukan permintaan untuk mendapatkan subsidi, kecuali sekolah Muhammadiyah pada tahun 1914. Lihat, Muhammad Sirozi, Politik Kebijakan pendidikan di Indonesia, (Jakarta: INIS, 2004), Seri INIS 2, hal. 19-22. 
bahasa Arab yang menjadi bagian pendidikan keislaman juga beragam meskipun di daerah tertentu menunjukkan keseragaman. Di Aceh misalnya, terdapat delapan kerajaan Islam, tetapi tingkatan institusi pendidikannya sama. Setiap desa memberikan program pendidikan dasar yang disebut Meunasah dan setiap masjid menyediakan pendidikan menengah yang disebut Rangkang. Program pendidikan lanjut, disebut dayang, terdapat di setiap Naggroe atau wilayah uleebalang, dan Dayah Teungku Chik. Program diploma diberikan di pusat kerajaan. Program pendidikan universitas diberikan di Jâmi'ah Baiturrahman di Banda Aceh, yang kemudian dialihkan ke dalam Masjid Raya Baiturrahman oleh Sultan Iskandar Muda, dan juga dipakai sebagai pusat kegiatan pengetahuan. ${ }^{137}$ Meskipun tidak diperoleh informasi pada tingkat apa pengajaran bahasa Arab diberikan, maka dengan menganalogikan dengan daerah lain, patut diduga bahwa pengajaran bahasa Arab diberikan pada tingkat dayang atau bahkan Rangkang.

Di kerajaan Islam Minangkabau (1500 M/1650 M), pada setiap negeri (desa) didirikan sebuah masjid untuk shalat Jum'at, dan di setiap kampung didirikan surau sebagai tempat mengaji al Qur'an dan shalat lima waktu. Menurut tradisi, anak yang berusia 7 tahun harus dipisah dari ibunya dan bermalam di surau sambil belajar al Qur'an. Inilah yang dinamakan Pengajian Qur'an. Setamat dari sini, beberapa murid meneruskan ke jenjang Pengajian Kitab pada tuan Syekh di sebagian negeri (desa). Di

137 Menurut Hasjmi sebagaimana dikutip oleh Muhammad Sirozi, kedelapan Kerajaaan Islam Awal di Aceh adalah Peureulak (1840), Lingga (986), Samudera/Pase (1042), Darussalam (1205), Beunua (1353), Pidier (ke-14), Jaya (1480), dan Aceh Darussalam (1511). Lihat, Ibid., hal. 35-36. 


\section{Alam Budi Kusuma : Transformasi Pengajaran Bahasa Arab}

tingkat inilah bahasa Arab diajarkan dan menjadi dasar pengajaran ilmu-ilmu keislaman lainnya. Karena murid begitu banyak, maka yang belajar pada tuan Syeikh hanyalah guru-guru tua, sebutan bagi guru-guru bantu yang mengajar murid-murid. Bila pada tingkat pertama, murid diajar satu demi satu, maka pada tingkat kedua murid diajar dengan sistem halaqah, duduk berlingkar menghadap guru besar (Syeikh). Sistem ini berlangsung sampai tahun 1908 atau 1909, saat madrasah-madrasah dengan sistem klasikal muncul, dipelopori oleh Syekh Abdullah Ahmad yang pada tahun 1909 mendirikan Madrasah Adabiyah. ${ }^{138}$

Di Jawa pada masa kerajaan Islam Mataram (sejak 1575 M) dikembangkan dua sistem pendidikan: 1) Pengajian Qur'an, tempat pengajaran al Qur'an dan pokok-pokok ilmu agama Islam, yang di satu desa bisa beberapa tempat. Modinlah yang menjadi gurunya. Laki-laki dan perempuan yang telah berusia 7 tahun atas kehendak orang tuanya harus belajar di sini; dan 2) Pengajian Kitab, tempat pendidikan murid-murid yang telah tamat mengaji al Qur'an. Guru-gurunya disebut Kyai Anom, biasanya Modin atau orang lain yang memenuhi kualifikasi. Tempat pengajiannya disebut pesantren. Pesantren ini dibedakan menjadi tiga tingkat: pesantren desa, pesantren besar (daerah kabupaten) yang diasuh oleh Kyai Sepuh/Kanjeng Kyai, dan pesantren keahlian (takhassus). Pengajaran bahasa Arab (Nahw dan Sharf) tampak diberikan pada pesantren besar. Cara pengajarannya adalah dengan sorogan, seorang demi seorang bagi muridmurid/santri-santri permulaan dan dengan bandungan (halaqoh)

138 Mahmud Yunus, Op. Cit., hal 33-63.

174 Jurnal Komunikasi dan Pendidikan Islam, Volume 4, Nomor 2, Desember 2015 
bagi santri-santri lanjut. ${ }^{139}$ Biaya pesantren dari masyarakat dan guru diberi gaji tanah sawah oleh kerajaan.

Di masa kolonial Belanda, mula-mula sistem Mataram Islam itu dibiarkan berjalan. Setelah perjanjian Gianti (1755), Belanda mulai melumpuhkan pengaruh Islam. Hasil pungutan dari masyarakat (zakat, serakah/iuran waktu nikah, wakaf, dan lain-lain) yang semula untuk pembiayaan pesantren dijadikan kas pemerintah; dan tanah yang menjadi gaji Modin/Kyai Sepuh dijadikan tanah gubernemen. Ketidakberpihakan pemerintah kolonial Belanda terhadap pendidikan Islam pada umumnya dan pengembangan bahasa Arab khususnya mencapai titik kulminasi dengan tidak diajarkannya membaca dan menulis latin dalam bahasa Arab (jawai/pegon) di sekolah-sekolah kolonial pada awal abad dua puluh. Tulisan Arab yang menjadi "simbol" kedekatan umat Islam dengan ajaran Islam dan telah memberikan ruang yang kondusif bagi pembelajaran bahasa Arab --banyak masyarakat yang dapat menulis dan membaca huruf latin-Arab meskipun mereka tidak mampu membaca dan menulis dengan bahasa Arab-- pada saat itu pun hilang dari peredaran. Poin penting sejarah itu ada yang menyebut mulai tahun 1901. Namun, tampaknya penentuan tahun itu hanya ingin menandai bahwa ada kemunduran pendidikan Islam sejak masa kolonial Belanda sampai dekade-dekade akhir masa kolonial. Hal ini karena tulisan Melayu Arab --seperti tercantum dalam Kurikulum

139 Menurut Nurcholish Madjid, sistem sorogan/weton adalah pengajaran yang inisiatifnya dari Kyai, baik dalam menentukan tempat, waktu maupun kitab sedangkan sistem bandungan adalah pengajaran atas permintaan seorang atau beberapa santri pada Kyai untuk diajarkan kitab tertentu. Lihat, Yasmadi, Op. Cit., hal. 67. 


\section{Alam Budi Kusuma : Transformasi Pengajaran Bahasa Arab}

HIS, Statuta 1914 No. 764-- masih dipakai dalam mata pelajaran bahasa Melayu. ${ }^{140}$

Kemunduran pendidikan Islam masa kolonial Belanda ini berlangsung sampai tahun $1900 \mathrm{M}$, saat ulama-ulama besar Indonesia yang beberapa lama mukim di Mekkah setelah menunaikan Haji pulang ke Indonesia dan mendirikan pondokpondok pesantren baru, yang membawa jiwa dan samangat baru. ${ }^{141}$ Sejak saat itu, pesantren terus berkembang dan mengadakan pembaharuan. Puncak pembaharuan terjadi pada tahun 1930-an, saat sejumlah alumni Timur Tengah yang berorientasi pembaharuan pulang ke tanah air. Pondok Modern Gontor, misalnya, yang didirikan pada tahun 1926 oleh Trimurti (Ahmad Sahal, Zainuddin Fanani, dan Zarkasyi) menanggalkan sistem pengajaran sorogan dan bandongan karena dipandang lambat membina kemampuan pemahaman, dan menggantinya dengan sistem klasikal yang mengatur kenaikan tingkat, pembagian kelas, pembatasan masa belajar, dan administrasi sekolah. ${ }^{142}$

Sistem klasikal ini juga dikembangkan dalam institusi pendidikan Islam model madrasah yang terutama dipelopori oleh dua organisasi Islam besar, Muhammadiyah dan Persatuan Islam (Persis) meskipun pengajaran bahasa Arab pada madrasahmadrasah kedua organisasi ini terlihat lebih sedikit daripada di pesantren. Peneguhan sistem klasikal ini terdapat pada tingkat perguruan tinggi Islam dan yang pertama kali dirintis oleh

140 S. Nasution, sejarah Pendidikan Indonesia, (Jakarta: Bumi Aksara, 1995), hal. 114.

141 Op. Cit., hal. 221-228.

142 Mahrus As'ad, "Ma'had al Gontor bayn al Jadîd wa al Taqlîd" dalam Studia Islamika, vol. 3, no. 4, 1996, hal. 167-168. 
Alam Budi Kusuma : Transformasi Pengajaran Bahasa Arab

Mahmud Yunus dan kawan-kawan yang tergabung dalam Persatuan Guru agama Islam (PGAI) di Padang dengan mendirikan Sekolah Tinggi Islam pada 9 Desember 1940 dan terdiri dari dua fakultas: Fakultas Syariah Agama (Islam), dan Fakultas Pendidikan dan Bahasa Arab. ${ }^{143}$

\section{Metode dan Teknik Pengajaran Bahasa Arab}

Metode pengajaran bahasa terkait dengan penyajian materi pelajaran bahasa. Pemilihannya sangat dipengaruhi oleh beberapa faktor, seperti latar belakang bahasa dan sosio-kultur murid, pengalaman guru, tujuan dari program bahasa yang diberikan, kedudukan bahasa asing tersebut dalam keseluruhan pendidikan yang dijalankan, dan waktu yang disediakan. ${ }^{144}$ Oleh karena faktor-faktor yang melingkupi berbeda, maka metode pengajaran bahasa Arab di Indonesia yang digunakan selama ini juga berbeda dan beragam.

Sebagaimana telah tersebut di atas bahwa pengajaran bahasa Arab mula-mula diadakan agar murid/santri memiliki kemampuan memahami dan mendalami al Qur'an dan Hadis, dan mudah mengikuti pelajaran ilmu-ilmu keislaman lainnya, seperti fiqh dan tafsir. Pilihan metode pengajaran kemudian jatuh pada metode gramatika-terjemah, sebuah metode yang memberikan dan menjanjikan kecakapan penguasaan berbagai kaidah gramatika Arab dan pemahaman atas teks-teks sumber keislaman yang belum berharakat, yang biasa disebut dengan kitab kuning. ${ }^{145}$

143 Op. Cit., hal. 117.

144 Muljanto sumardi, Pengajaran Bahasa Asing: Sebuah Tinjaun dari Segi Metodologi, (Jakarta: Bulan Bintang, 1975), cet. II, hal. 12.

145 Kitab kuning adalah istilah yang ditujukan untuk satu nama buku karangan atau hasil karya para ulama pada abad pertengahan 


\section{Alam Budi Kusuma : Transformasi Pengajaran Bahasa Arab}

Biasanya pelajaran yang mula-mula diajarkan adalah ilmu Sharf dan kemudian ilmu Nahw. Buku-buku yang dipakai antara lain: al Maqshûd (nazam), al 'Awâmil (nazam), al Imrithi (nazam), al Ajrûmiyah, al Kailani, Alfiyah (nazam), dan Ibnu Aqîl.

Teknik pengajaran ilmu Sharf adalah dengan menghafal tashrif yang sembilan, tashrif fi'il madli yang empat belas, tashrif fi'il mudlari' yang empat belas, tashrif masdar, dan tashrif isim fa'il. Tashrif itu dihafal dengan lagu yang menarik hati. Teknik yang mendahulukan ilm Sharaf dari pada ilmu Nahw ini dipandang sesuai untuk murid/santri di Indonesia. Di samping itu, murid/santri amat cakap mentashrifkan kata-kata. Apabila mengetahui satu kata, dengan mudah mereka dapat mentashrifkannya. Sayangnya, kata-kata tashrif itu tidak dipakai dalam kalimat, tetapi hanya berupa kata-kata. Teknik pengajaran ilmu Nahw adalah dengan membaca matan kitab tertentu dalam bahasa Arab, lalu menerjemahkannya ke dalam bahasa daerah/Indonesia, yaitu terjemah kata demi kata. Sesudah itu, barulah maksudnya diterangkan. Yang dipentingkan dalam

yang ditulis dengan bahasa Arab yang berisi pemikiran mereka tentang masalah agama. Disebut kitab kuning, karena kertas yang digunakan untuk menulis berwarna kuning, tetapi setelah mengalami kemajuan sebagaimana yang ada sekarang ini sudah banyak yang tidak menggunakan kertas kuning. Dikalangan santri tidak lagi menyebut dengan istilah kitab kuning, tapi cukup dengan menunjuk nama kitab itu sendiri. Lihat M. Dawam Rahardjo, Pergulatan Dunia Pesantren (Jakarta: P3M, 1985), hal. 55. Kitab Kuning merupakan buku yang digunakan sebagai pedoman dalam proses belajar mengajar di pesantren, ditulis dengan bahasa Arab gundul ( tidak memakai harakat). Kitab kuning selalu dipandang sebagai kitab keagamaan berbahasa Arab atau berhuruf Arab sebagai produk pemikiran ulama-ulama masa lampau (as-salaf) yang ditulis dengan format khas pra modern sebelum abad ke-17-an M. Lihat. Said Aqiel Siradj, Pesantren Masa Depan, "Wawancara Pemberdayaan dan Transformasi Pesantren” (Bandung: Pustaka Hidayah, 1999), hal. 222. 
pelajaran nahwu adalah menghafal kaidah/definisi, seperti: apa al kalam itu? Apakah fi'il? Apakah isim?. Contoh-contoh untuk kaidah/definisi itu kebanyakan terdiri dari Zaid dan Umar,

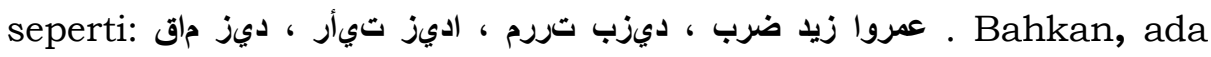

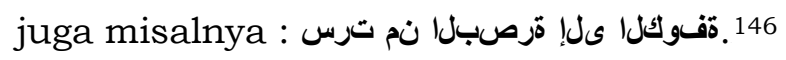

Dalam kenyataannya, metode dan teknik yang dominan dipakai di Indonesia sampai akhir abad ke-19 ini kebanyakan melahirkan murid/santri yang tahu tentang bahasa, bukan mahir dalam menggunakan bahasa. Alih-alih melahirkan santri/murid yang mampu mengekspresikan dan mengkomunikasikan pikiran dan perasaannya dalam bahasa Arab, metode ini bahkan melahirkan tidak sedikit murid/santri yang hanya hafal berbagai kaidah nahwu-sharf, tetapi tidak mampu mengaplikasikannya ketika membaca teks-teks Arab, seolah-olah mengetahui kaidah adalah satu hal dan membaca teks-teks Arab tanpa harakat adalah hal lain. Fenomena ini tidak saja khas produk madrasah atau pesantren masa lalu, tetapi bahkan terjadi pada murid/santri dari beberapa madrasah/pesantren sekarang. Tampaknya, ini akibat dari penguasaan tata bahasa Arab yang tidak diarahkan untuk membuat kalimat-kalimat Arab yang gramatikal atau menganalisis kalimat-kalimat Arab, sederhana dan kompleks, dari sisi garmatika Arab, tetapi hanya sebatas pengetahuan tentang tata bahasa Arab itu sendiri.

Seiring dengan sistem klasikal yang diterapkan oleh institusi-institusi pendidikan sejak awal abad ke-19, baik model madrasah atau pesantren, maka metode dan teknik pengajaran bahasa Arab pun mulai bergeser. Bila sebelumnya bahasa Arab yang diajarkan adalah bahasa Arab pasif, maka sejak saat itu

146 Mahmud Yunus, Op. Cit., hal. 46-48. 


\section{Alam Budi Kusuma : Transformasi Pengajaran Bahasa Arab}

pelajaran-pelajaran yang diberikan juga mengarah pada kemampuan berbahasa Arab secara aktif. Dalam rencana pelajaran Tsanawiyah al Jami'ah Islamiyah (Sungayang, Batusangkar) 1931, misalnya, bidang bahasa Arab meliputi: membaca, bercakap-cakap/mengarang, hafalan, qawaid/NahwuSharf. Hal yang sama juga dapat dilihat pada Normal Islam/Kuliah Muallimin Islamiyah Padang dan Sekolah Tinggi Islam yang dirintis oleh Mahmud Yunus dan kawan-kawan di atas.

Mata pelajaran bahasa Arab pada yang pertama meliputi: mengarang/berpidato, muthala'ah, mahfudhat, qawaid, dan adabul lughah; sedang mata kuliah-mata kuliah seperti mengarang, hafalan, muthala'ah, dan pidato, dan adabul lughah menjadi bagian dari mata kuliah bidang bahasa Arab pada yang kedua, bahkan pada Fakultas Syariat (Islam). ${ }^{147}$

Metode yang dikembangkan adalah metode langsung, sebuah metode yang mensyaratkan komunikasi dengan bahasa Arab, kecuali terpaksa, selama proses pembelajaran berlangsung, baik antara guru dan murid/santri maupun antar murid/santri. Menurut Mahmud Yunus, salah satu pelopor dalam pembaharuan pengajaran bahasa Arab di Indonesia, selama ini sistem dan metode yang ada hanya ditujukan untuk memahami dan menerjemahkan teks bahasa Arab. Baginya, murid harus juga mempunyai kemampuan untuk mendengarkan dan mengkomunikasikan pikiran mereka dalam bahasa Arab, apalagi hubungan masyarakat Indonesia dengan negara-negara Timur Tengah terus meningkat. Karena itu, dalam pandangannya metode

147 Ibid., hal. 106-107 dan 120.

180 Jurnal Komunikasi dan Pendidikan Islam, Volume 4, Nomor 2, Desember 2015 
pengajaran yang selama ini berorientasi pada tata bahasaterjemah harus diganti dengan metode langsung.

Muthala'ah pun menjadi pelajaran terpenting, karena dapat mengembangkan percakapan, pendengaran, dan pemahaman. Bahkan, dari pola-pola kalimatnya, dapat dikembangkan menjadi pelajaran tata bahasa. Materi-materi pelajaran bahasa Arab, menurutnya, juga perlu disesuaikan dengan alam Indonesia supaya dapat menarik perhatian murid. Buku-buku yang ada lebih banyak diterbitkan di Timur Tengah sehingga ilustrasi maupun cerita-ceritanya diwarnai oleh budaya negeri-negeri tersebut. Akibatnya, murid akhirnya terasing dan cepat bosan. ${ }^{148}$

Tampaknya, Mahmud Yunus menggunakan pendekatan komunikatif dalam pemikirannya tentang pengajaran bahasa Arab, bukan pendekatan struktural yang berlaku sebelumnya. Penggunaan metode langsung pada institusi pendidikan Islam di Jawa dipelopori oleh Pondok Modern Gontor. Dengan penyajian gramatika Arab secara induktif, di samping latihan intensif qira'ah, insya,' dan muhâdtasah, metode langsung ini dapat melahirkan murid/santri yang mampu berkomunikasi dengan bahasa Arab, terutama lisan.

Dalam perkembangannya, pengajaran bahasa Arab pada institusi pendidikan modern tidak hanya menggunakan metode langsung, tetapi terus mengikuti pembaharuan yang terjadi dalam dunia pengajaran dengan, misalnya, menggunakan metode audiolingual, sebuah metode yang bahan pelajarannya dicirikan oleh teks dialog untuk dihafalkan dan dril-dril pola kalimat. ${ }^{149}$

148 Didin Syafruddin, "Mahmûd Yûnus wa Ittijâhâtuhu fî Tajdîd Ta'lîm al Lughah al "Arabiyyah bi Indûnîsiyyah" dalam Studia Islamika, vol 3, no 4, 1996, hal. 1775-176.

149 Ahmad Fuad Effendy, Op. Cit., hal. 50. 


\section{Alam Budi Kusuma : Transformasi Pengajaran Bahasa Arab}

Selanjutnya, digunakan metode eklektik sebagaimana telah dinyatakan secara eksplisit dalam kurikulum madrasah (Tsanawiyah dan Aliyah) tahun 1994 meskipun penerapannya disebut-sebut tidak jelas. ${ }^{150}$

Penyajian berbagai materi bahasa Arab juga mengalami perubahan. Bila sampai 1960-an pesantren dan madrasah menggunakan "sistem terpisah," dalam arti pelajaran-pelajaran yang diarahkan untuk memberikan masing-masing kemahiran berbahasa (mendengar, membaca, menulis, dan berbicara) diberikan secara terpisah, maka sejak pertengahan 1970-an di sekolah-sekolah, madrasah, dan sebagian pesantren digunakan "sistem terpadu" (sistem ini sebenarnya sudah digagas oleh Mahmud Yunus pada tahun 1930-an). Dengan sistem terakhir ini, empat kemahiran berbahasa itu didisain dalam satu pelajaran. Namun, ada lembaga yang menggabungkan kedua sistem dalam pola pengajaran bahasa Arab. Pondok Modern Gontor, umpamanya, menerapkan sistem terpadu selama satu tahun pertama, sehingga hanya ada mata pelajaran bahasa Arab oleh satu guru dengan jumlah jam lebih dari 10 jam/minggu; dan sistem terpisah mulai kelas dua. ${ }^{151}$

\section{E. Arah Mutakhir Pengajaran Bahasa Arab}

Ketika metode gramatika-terjemah dalam pengajaran bahasa Arab tidak mampu memberikan kecakapan menyimak dan berbicara, maka muncullah metode langsung. Meski terbukti dapat memberikan kecakapan menyimak dan berbicara, ternyata metode terakhir ini memiliki kelemahan dalam membaca dan

150 Ibid., hal. 71.

151 Ibid., hal. 79. 
menulis. Tidaklah heran apabila sebuah institusi pendidikan terkadang dihubungkan dengan satu atau dua, bukan dengan keseluruhan kemahiran berbahasa. Misalnya, Pondok Modern Gontor biasanya dihubungkan dengan kecakapan berbicara, dan Pesantren Tebuireng Jombang dengan membaca. Begitu ada yang mencoba menggabungkan empat kemahiran tersebut, maka institusi tersebut terbukti kurang untuk tidak menyebut tidak berhasil, sehingga bahkan tidak menonjol dalam satu kemahiran pun.

Kenyataan tidak adanya precedent yang, dengan mengaplikasikan satu atau dua metode, dapat membuahkan hasil seluruh kemahiran berbahasa, maka dalam perkembangan terakhir di beberapa institusi pendidikan Islam, dari tingkat dasar sampai perguruan Tinggi, terjadi semacam "kekurangsabaran," sehingga yang tampak adalah ketidakmenentuan: revisi kurikulum dan silabi sering dilakukan. Ketidakmenentuan ini, menurut Ahmad Fuad Effendy, dapat dilihat dari beberapa segi. Pertama, dari segi tujuan terdapat kerancuan antara mempelajari bahasa sebagai tujuan dan sebagai alat menguasai pengetahuan lain yang berbahasa Arab. Kedua, dari segi bahasa yang dipelajari terdapat ketidakmenentuan apakah bahasa Arab klasik, modern atau bahasa Arab sehari-hari. Ketiga, dari segi metode terdapat kegamangan antara mempertahankan yang lama dan menggunakan yang baru.

Kondisi pengajaran bahasa Arab di sekolah umum lebih tidak menentu lagi, bukan saja dari segi bentuk, melainkan bahkan eksistensinya. Dalam struktur program kurikulum SMA (sekarang SMU) Tahun 1975, bahasa Arab ditetapkan sebagai mata pelajaran bahasa asing pilihan dengan status sebagai bidang 


\section{Alam Budi Kusuma : Transformasi Pengajaran Bahasa Arab}

studi mayor pada jurusan Bahasa dan bidang studi minor pada jurusan IPS. Namun, GBPP Bahasa Arab pada kurikulum tersebut tidak ada. GBPP untuk bahasa Arab baru disusun pada kurikulum 1984 dengan pendekatan struktural dan aural-oral, dengan 2-3 jam per minggu, dan diberikan mulai kelas dua. Pada kurikulum 1994 terjadi perubahan kurikulum yang signifikan. Penjurusan baru dimulai kelas tiga, sehingga bahasa asing pilihan hanya diberikan selama satu tahun dengan 9 jam/minggu dan itu pun hanya pada jurusan Bahasa. Dalam kurikulum tersebut ditetapkan penggunaan pendekatan komunikatif. ${ }^{152}$

\section{F. Pengajaran Bahasa Arab di Masa Depan: Sebuah Prediksi}

Ketidakmenentuan di atas bukan berarti tidak disadari oleh banyak kalangan, terutama pihak-pihak yang terkait dan bertanggung jawab atas pengembangan bahasa Arab. Banyak upaya perbaikan, pembinaan dan pembaharuan pun dilakukan berbagai kalangan, terutama pada tingkat Aliyah/menegah dan perguruan tinggi. Di berbagai sekolah dikembangkan model pengajaran bahasa Arab dengan menciptakan apa yang disebut sebagai "bî-ah 'arabiyyah" (lingkungan tempat bahasa Arab menjadi alat komunikasi). Lingkungan ini diwujudkan dengan penerapan model boarding school (sekolah berasrama). Dengan model ini, sekolah dapat mengontrol siswa untuk selalu menggunakan bahasa Arab sebagai alat komunikasi mereka. Dengan demikian, mereka akan memiliki kecakapan berkomunikasi dengan bahasa Arab secara baik dan lancar. Model sekolah ini dipelopori oleh pendirian madrasah-madrasah Aliyah model (MAPK, Madarasah Aliyah Program Khusus) pada akhir

152 Ibid., hal. 25.

184 Jurnal Komunikasi dan Pendidikan Islam, Volume 4, Nomor 2, Desember 2015 
tahun 80-an (tepatnya tahun 1987). Selama di asrama, siswa dilatih untuk memperoleh kecakapan dalam bahasa Arab, baik pasif maupun aktif.

Keberhasilan madrasah model ini paling tidak dalam kasus MAPK Jember, lebih dari separuh lulusan tiga angkatannya kini menjadi staf pengajar di berbagai perguruan tinggi Islam negeri dan swasta di Indonesia telah mengilhami banyak perguruan tinggi Islam untuk mengembangkan model pengajaran bahasa Arab intensif, dengan hanya memberikan mata kuliah bahasa selama dua semester pertama dan mengharuskan mahasiswa untuk tinggal di asrama selama tahun pertama itu. UIN Malang di sini dapat disebut sebagai pioner dalam pengajaran bahasa Arab model intensif ini. Selama tahun pertama semua mahasiswa di sana, dari jurusan semua jurusan, dilatih dan didik untuk menggunakan bahasa Arab secara pasif dan terutama aktif, di samping mereka harus tinggal di asrama dan didampingi oleh seorang pembimbing bahasa Arab.

Usaha pembaharuan pengajaran bahasa Arab di Indonesia dalam skala yang lebih luas sebenarnya telah dimulai pada wal tahun 1970-an dengan dukungan Departemen Agama R.I. Berbagai workshop bagi penyusunan silabus pengajaran bahasa Arab dan serangkaian penataran guru bahasa Arab diadakan. Berikut rekomendasi hasil beragam kegiatan tersebut.

1. Untuk tingkat dasar, digunakan pendekatan aural-oral dan integrated system, dengan metode mimicry-memirization dan pattern-practice.

2. Untuk tingkat menengah, sama dengan tingkat dasar ditambah pendekatan polysistemic. 


\section{Alam Budi Kusuma : Transformasi Pengajaran Bahasa Arab}

3. Untuk tingkat lanjut, digunakan metode langsung dan metode gramatika-terjemah.

Di lingkungan Depdiknas sendiri telah dikembangkan penggunaan pendekatan komunikatif untuk pengajaran bahasa. GBPP bahasa Arab kurikulum SMU tahun 1994 pun dikembangkan berdasarkan pendekatan komunikatif, yang kemudian diikuti oleh GBPP bahasa Arab Madrasah Aliyah tahun 1996.153

Selanjutnya, dari sisi eksternal pada dasarnya telah tumbuh suasana yang memungkinkan bahasa Arab dapat berkembang dengan baik dan mengejar ketertinggalannya dari bahasa asing lain. Sejak ICMI berdiri, masyarakat Indonesia tidak lagi segan-segan untuk menampakkan simbol-simbol keislaman mereka. Lingkaran-lingkaran studi keislaman bermunculan, bahkan di perguruan tinggi umum. Organisasi-organisi internal kampus di beberapa perguruan tinggi umum kini malahan telah dikuasai oleh lingkaran-lingkaran studi ini. Demikian pula dengan para politisi dan artis. Mereka tidak malu-malu lagi menunjukkan diri sebagai muslim. Ungkapan salam dan kosa-kosa kata bernuansa Islam sering meluncur dari ucapan mereka. Pengajianpengajian kalangan selebritis ini pun tidak jarang digelar. Semua itu seolah meneguhkan bahwa bahasa Arab senantiasa "dibutuhkan" karena keberadaannya yang tidak terpisahkan dari ritual agama Islam. Kebutuhan terhadap bahasa Arab adalah sebuah peluang yang menjanjikan keuntungan besar, material dan immaterial.

Pada sisi lain, mobilitas masyarakat semakin tinggi. Seolah tidak ada waktu rehat bagi masyarakat yang sedang

153 Ibid., hal. 26.

186 Jurnal Komunikasi dan Pendidikan Islam, Volume 4, Nomor 2, Desember 2015 
memodernisasi diri ini. Mobilitas ini digerakkan dan didorong oleh kemajuan di berbagai bidang yang begitu pesat, terutama bidang ekonomi dan teknologi. Kemakmuran ekonomi dan kemajuan teknologi ternyata telah menggiring masyarakat untuk meminjam istilah ekonomi dengan sedikit perubahan meraih hasil maksimal dengan energi minimal. Ini berarti bahwa efisiensi dan efektifitas dalam semua hal menjadi prioritas. Dua hal inilah yang harus dipertimbangkan oleh para praktisi pengajaran bahaas Arab dalam memanfaatkan peluang bagi pengembangan dan bahkan "pemasaran" bahasa Arab. Pendek kata, karena makmur, masyarakat memposisikan diri sebagai "tuan" yang memiliki banyak sekali pilihan dan harus dilayani. Masyarakat seperti inilah yang menjadi "pasar" pengajaran bahasa Arab.

Atas dasar ini, maka pengajaran bahasa Arab di masa depan dapat diprediksi akan memanfaatkan berbagai temuan modern, terutama bidang teknologi. Bila sekarang telah muncul pengajian atau belajar al Qur'an melalui SMS, maka di masa depan hal yang sama juga bisa terjadi pada pengajaran bahasa Arab. Memaksa orang untuk datang belajar bahasa Arab ke tempat tertentu akan sulit dan, karena itu, mereka harus diberi hidangan bahasa Arab, kapan dan di mana pun mereka berada dan menginginkannya. Selain itu, pengajaran bahasa Arab di masa mendatang akan menggunakan berbagai sarana dan perlengkapan yang terbukti telah mampu memasyarakatkan bahasa asing lain. Kemajuan teknologi di bidang komunikasi telah membuat ruang menjadi terbuka dan sempit, sehingga para praktisi pengajaran bahasa Arab dapat mencari tahu tentang berbagai hal dalam pengajaran bahasa asing lain. 


\section{Alam Budi Kusuma : Transformasi Pengajaran Bahasa Arab}

\section{G. Penutup}

Bahasa Arab pada dasarnya memiliki akar yang kokoh dan telah dikenal oleh masyarakat Indonesia sejak agama Islam masuk ke wilayah nusantara pada ke-11 atau ke-12 M. Praktek berbahasa Arab pun telah berlangsung sejak saat itu meskipun pengajaran bahasa Arab baru dilakukan setelah ada kesadaran dan kebutuhan untuk memahami al Qur'an, Hadis, dan ilmu-ilmu keislaman lainnya.

Pada masa pra-kolonial Belanda, pengajaran bahasa Arab telah memiliki milieu yang cukup kondusif. Hal ini karena adanya dukungan penuh dari penguasa kerajaan-kerajaan Islam. Salah satu tanda adanya milieu kondusif ini adalah digunakannya huruf Arab sebagai media tulis bahasa Melayu sehingga muncul istilah bahasa Arab-Melayu dan Huruf Pegon atau Jawi. Penggunaan huruf Arab-Melayu dalam berbagai tulisan ini berlangsung sampai dekade-dekade awal abad ke-20. Pada masa pemerintahan kolonial Belanda, pengajaran bahasa Arab mengalami kemunduran seiring dengan kebijakan diskriminatif dan tidak bersahabat pemerintah kolonial terhadap umat Islam dan pendidikan Islam. Kondisi ini berlangsung sampai tahun 1900-an, saat pembaharuan pengajaran pengajaran bahasa Arab dimulai. Puncak pembaharuan ini terjadi pada tahun 1930-an. Pada masa awal kemerdekaan sampai awal Orde Baru keberpihakan pemerintah terhadap pendidikan Islam dan pengajaran bahasa Arab juga belum tampak, karena baru pada tahun 1975 bahasa Arab ditetapkan sebagai mata pelajaran bahasa asing pilihan dengan status sebagai bidang studi mayor pada jurusan Bahasa dan bidang studi minor pada jurusan IPS. 
Sejak kali pertama sampai sekarang pengajaran bahasa Arab di Indonesia mengalami pergeseran dan perubahan: dari hanya sistem lesehan menjadi bertambah dengan sistem klasikal; dari menggunakan metode gramatika-terjemah lalu menggunakan metode langsung; dari penyajian materi bahasa Arab dengan sistem terpisah semata kepada penggunaan sistem terpadu juga; dan dari menggunakan pendekatan struktural menjadi pendekatan komunikatif.

Meskipun telah mencoba beragam pendekatan, metode, dan sistem penyajian, keberhasilan pengajaran bahasa Arab tampak masih jauh dari yang diharapkan, apalagi bila dibandingkan dengan pengajaran bahasa asing lain seperti bahasa Inggris. Hal ini membuat beberapa institusi pendidikan Islam "tidak sabar" sehingga mengambil langkah-langkah yang disinyalir sebagai "tidak menentu" dalam pengajaran bahasa Arab. Ketidakmenentuan ini mencakup tujuan pengajaran bahasa, bahasa yang dipelajari, dan metode yang dipakai.

Namun, ketidakmenentuan ini merupakan fenomena yang disadari, sehingga berbagai perbaikan terus diupayakan oleh banyak kalangan. Penciptaan bî-ah 'arabiyyah (milieu bahasa Arab) dan model pengajaran bahasa Arab intensif dengan boarding school (sekolah berasrama) pun menjadi pilihan. Usaha perbaikan secara luas didukung penuh oleh Departemen Agama R.I. Di samping itu, sisi ekternal ternyata sangat mendukung bagi pengembangan dan "pemasaran" bahasa Arab. Hanya saja, sisi eksternal sebagai pangsa pasar bahasa Arab ini adalah sebuah masyarakat yang sedang memodernisasi diri, mengalami mobilitas tinggi, dan sedang menikmati kemakmuran ekonomi dan 
kemajuan teknologi. Efisiensi dan efektifitas menjadi prioritas masyarakat seperti ini.

Oleh karena itu, pengajaran bahasa Arab di masa depan akan mempertimbangkan kondisi masyarakat yang sangat mobile ini dengan cara memaanfaatkan berbagai kemajuan teknologi bagi pengajaran bahasa Arab. Pengajaran bahasa Arab juga tidak dapat mengesampingkan berbagai sarana dan perlengkapan yang terbukti mampu memasyarakatkan bahasa asing lain untuk digunakan dalam pengajaran bahasa Arab.

Memang, posisi bahasa Arab tidak saja ditentukan oleh faktor-faktor eksternal, tetapi lebih karena cara "pemasaran" bahasa Arab melalui "kemasan" pengajaran yang handal dan menarik. 


\section{DAFTAR PUSTAKA}

As'ad, Mahrus, "Ma'had al Gontor bayn al Jadîd wa al Taqlîd" dalam Studia Islamika, vol. 3, no. 4, 1996.

Effendy, Ahmad Fuad, Metodologi Pengajaran Bahasa Arab, (Malang: Misykat, 2004).

Hasbullah, Sejarah Pendidikan Islam di Indonesia, (Jakarta: PT RajaGrafindo Persada, 1996), cet. II.

Mastuhu, Dinamika Sistem Pendidikan Pesantren, (Jakarta: INIS, 1994), Seri INIS 20.

Nasution, S., Sejarah Pendidikan Indonesia, (Jakarta: Bumi Aksara, 1995).

Parera, Jos Daniel, Pengantar Linguitik Umum: Kisah Zaman, (Ende-Flores: Nusa Indah, 1977).

Saussure, Ferdinad de, Pengantar Linguistik Umum, terjem. Oleh Rahayu S. Hidayat, (Yogyakarta: Gadjah Mada University Press, 1996), cet. III.

Sirozi, Muhammad, Politik Kebijakan pendidikan di Indonesia, (Jakarta: INIS, 2004), Seri INIS 2.

Sudarno, Kata Serapan dari Bahasa Arab, (Jakarta: Arikha Media Cipta, 1992), cet. II.

Sumardi, Muljanto, Pengajaran Bahasa Asing: Sebuah Tinjaun dari Segi Metodologi, (Jakarta: Bulan Bintang, 1975), cet. II.

Syafruddin, Didin, "Mahmûd Yûnus wa Ittijâhâtuhu fî Tajdîd Ta'lîm al Lughah al "Arabiyyah bi Indûnîsiyyah" dalam Studia Islamika, vol 3, no 4, 1996.

Yâqût, Mahmûd Sulaimân, Manhaj al Bahst al Lughawy, (Iskandariyah: Dâr al Ma'rifah al Jâmi'iyyah, 2002).

Yasmadi, Modernisasi Pesantren: Kritik Nurcholish Madjid terhadap Pendidikan Islam Tradisional, (Jakarta: Ciputat Press, 2002). 
Yunus, Mahmud, Sejarah Pendidikan Islam di Indonesia, (Jakarta: Hidakarya Agung, 1996).

Zuhairini dkk, Sejarah Pendidikan Islam, (Jakarta: Bumi Aksara \& Ditjen Pembinaan Kelembagaan Agama Islam Depag RI, 1997), cet. V. 